\title{
Constructionist basis of composing and translating political speeches: A case study of President Trump's inaugural address
}

\author{
Nataliia Talavira $^{* 1}$ \\ ${ }^{1}$ Nizhyn Gogol State University, Nizhyn, Ukraine
}

\begin{abstract}
Application of the principles and tenets of cognitive linguistics to translation studies rests on the assumption that both of them employ the same meaning process while working with a text. Procedures implemented to translate the inaugural address of American President Trump have been regarded from the point of view of Construction Grammar. The construction is viewed as the main translation unit representing source linguistic material below the level of the text. The paper singles out from the translation of President Trump's inaugural address equivalent constructions with identical form and meaning and non-equivalent pairings indicating transformations of structure or semantics in the original constructions. Syntactical modifications include the change of word order, grammar tenses or omission of construction component, while lexical transformations result in generalization, carried out by words with more abstract meaning than those in the source construction; simplification, representing separate objects or features from the array of denoted in the source pairing; and specification accentuating and detailing particular entities.
\end{abstract}

\section{Introduction}

Although the practice of translation has long been established, the study of the field has now become one of the most active and dynamic areas of research encompassing many new approaches, including cognitive linguistics [see: 1]. This branch of linguistics argues that language reflects patterns of thought and "provides a well developed means of encoding and transmitting complex and subtle ideas" [2, p. 5-6] bringing together thought, language and culture in the speakers' cognitive context [3].

The focus on meaning is the common denominator for cognitive linguistics and translation studies. Working on a text a translator should first form its initial mental representation that is identical both during the process of creating an original text and its further translation into the target language.

As is known, text generation includes five stages consistent with the canons of ancient rhetoric: invention, i.e. topic choice; disposition, concerning textual arrangement of ideas; elocution, naming the arguments [4]; memory and delivery, that are combined into performance, dealing with various formats in which the information reaches the addressee.

In its turn, translation is not just a simple transfer of words from one language onto the other that looks for the closest equivalent. Translation is also the process of concentration on the text itself and maximizing the amount of information to be gleaned [5, p. 406] from

\footnotetext{
${ }^{*}$ Corresponding author: nataliia.talavira@ndu.edu.ua
} 
studying the lexicon, the grammatical structure, and the communication situation of the source language text [6] with further recoding its meaning into a target text "using a different linguistic code" [7, p. 283].

D. Alamargot and L. Chanquoy [8] distinguish four levels of translation: elaboration, linearization, formulation and graphic execution. Elaboration consists of "retrieving all sets of ideas about a topic which is defined by a part of a text plan" [8, p. 71]. The process implies focusing not exclusively on the linguistic surface level but text comprehension, and relating the text to the extra-textual world [9, p. 69]. This level corresponds to the rhetorical stage of invention. The second level is linearization of a preverbal message, i.e. transformation of concepts into words [8, p. 74], and is related to rhetorical disposition. The level of the text formulation implies "matching preverbal message elements with grammatical and lexical structures so as to produce a verbal entity, a sentence" [8, p. 78]. The translator generates the emerging text, i.e. its overall style and linguistic representation of ideas from the source text, monitoring the quality of the target product. This level corresponds to elocution, which deals with word choice, sentence structures, and figures of speech. The translation stage of graphic execution, i.e. written transcription of the processed phrase, sentence or text $[8$, p. 88], correlates with performance. As can be seen, the mechanisms of composing and perception of the source and the target texts are the same, proving the possibility of applying tenets and methods of cognitive linguistics to translation studies.

One of the trends of cognitive linguistics is Construction Grammar developed by A. Goldberg [10] claiming that the main cognitive linguistic unit is a construction, i.e. a pairing of form with meaning and function [11, p. 209], belonging to the lexicogrammatical language sublevel. It implies that there is no clear-cut difference between grammar and lexicon [13, p. 219]. Construction have three specific features important for translation: first, their meaning cannot be derived from its components [10, p. 4], e.g. the civilized world, face challenges; second, they are learned due to frequent input and stored in a generalized form in memory while their manifestations are used in speech [12, p. 436]; third, they directly reflect human experience and conceptual organization [2, p. 669]. Thus, the constructionist approach in our study implies the use of pairings of form with meaning and function to render both linguistic and semantic equivalence below the level of syntax without focusing predominantly on form [7, p. 284].

Constructions as a language unit have been applied to study their role in linguistic processing [14] and generalizations [15], in language acquisition [12], cross-linguistic [16] and translation studies as a means of solving constructional mismatch between different languages [7]. As noted above, constructions can not only reflect processes taking place at the point of construing a text but also at the stage of its translation into the target language. Thus, the paper focuses on analyzing translation strategies and procedures in political discourse, namely inaugural address delivered by a newly elected president to begin their leadership and to lay out the political principles that will govern the new administration [17, p. 42] for the nation and the whole world. To avoid misunderstanding it is important to find equivalent variants of translating the constructions that represent their ideas.

The aim of the study is to develop a method of applying morphosyntactic constructions to translating inaugural address of American President Donald Trump (2017) into Ukrainian.

The tasks of this article are to determine if the same pairings of form and meaning exist in the target language; to clarify what strategies and procedures translators resort to in order to solve constructional mismatch; to differentiate the types of construction modifications suitable for rendering ideas in the translated inaugural. 
The data for the study are derived from the inaugural address of President Trump [18] and its translation into Ukrainian obtained from the online source on uk.wikisource.org [19].

The structure of the paper is as follows: Section 2 defines the data and method implemented to translate the inaugural; Section 3 suggests a study of equivalent and nonequivalent constructions used in the Ukrainian language when translating President Trump's inaugural; Section 4 provides discussion of the results.

\section{Theoretical prerequisites and methods}

The translation resting on transference of meaning from one language to another depends on the strategy the translator adheres to. L. Venuti [20, p. 240] indicates that translation strategies "involve the basic tasks of choosing the foreign text to be translated and developing a method to translate it." And while a strategy concerns the whole text, including analysis of the source language (SL) and the target language (TL), translation procedures are used for sentences and the smaller units of language [21, p. 81] helping the translator to determine accurate and effective means of semantic and syntactical transformations.

The choice of the strategy is determined by the genre of the text, as the translator has to decide on the necessary adaptation to make the text available to wider readers. In case of the inaugural address, the goal is to reconstruct the ideas close to the original text due to the peculiarities of the latter. The inaugural is treated as a "unidirectional speech presented by the president to the audience," meaning that the president has the ability to address the citizens directly [22], without immediate audience feedback in a formal setting [23, p. 233]. Inaugurals are the first opportunity for the newly elected president to discuss American politics and their role in it [24], signaling the start of a new president's term in office: the president begins to "enact the presidential role" [17, p. 42; 25]. Delivering the speech to the whole nation and the world, the rhetor construes the vision of the future of the country and global issues, imposing their own stance and mobilizing the support of the powers that be [26, p. 276], inspiring nonpartisanship and consensus in America, and striving to establish national unity [27, p. 171]. In this sense, inaugural speeches are typical 'policy documents' as they deal with the political aims and intentions of the government and its plans for implementing this program [28, p. 40]. The influence of the inaugural address and its significance both for the rhetor and the addressee makes it vital to provide an accurate and equivalent translation in the TL.

The inaugural address is rhetorical by nature, as the newly elected president intends to persuade the audience of their suitability for this role [29, p. 2408], manifesting rhetorically the ability to lead and to be the symbolic head of state [17, p. 396]. In its turn, rhetoric is regarded as the art of persuasion [30, p. 5], communication that tries to coordinate social action, to manipulate human choices on specific matters requiring immediate attention [31, p. 2-3]. All these features must be adequately represented in the translated text. The inaugural is a prepared public speech with rhetorical canons and modes of persuasion implemented to compose and deliver it. Canons are used by rhetors to determine the structure of the speech, whereas modes of persuasion serve as ethical strategies that represent the speaker's appeal to the audience [32; 33, p. 517]. They include three rhetorical devices: ethos, i.e. credibility, competence and trustworthiness of the speaker; pathos, the emotional appeal; and logos, the argumentation and reasoning in the address [34, p. 236]. Each rhetor applies different linguistic units when appealing to these modes of persuasion, so it is necessary to preserve the original rhetorical devices in the translated text.

As is known, inaugurals aim at inspiring the audience to support the president's course, to invoke emotions [17, p. 397] appealing to pathos that appears to be a powerful means of 
winning the addressee over. Being based on passion or emotion [35, p. 574], pathos determines particular behaviour and is responsible for pushing us into action [34, p. 137]. As S. Potapenko claims [36, p. 156], pathos is interconnected with human basic needs: first, emotion is often the driving force behind motivation, positive or negative, and second, there is the correspondence between Aristotle's list of emotions and the needs singled out by A. Maslow [37, p. 37]: physiological, safety, belongingness, reputation or esteem, and selfactualization. The structuring of the original texts is determined by the above mentioned basic needs, so linguistic units denoting their satisfaction or negligence should be faithfully translated.

The central assumption in our work is that the most appropriate way to provide an accurate and effective translation of any inaugural address is the application of morphosyntactic constructions due to several reasons. First, constructions can be used to translate any ready-made linguistic unit consisting of anything from a morphological element or lexical item to a complex and abstract syntactic pattern [38, p. 14; 39, p. 6]. Second, such pairings can be freely combined in order to form various expressions if they are not in conflict with each other [40, p. 21] which means that a segment of a text necessary to establish an equivalence in the TL can be expanded. Third, the meaning of a construction arises due to its frequent use in situations. Such content becomes entrenched in mind through repeated association [41, p. 187] and the generalized meaning and form of a construction are stored in memory. As a result, the translator needs less cognitive effort to find an equivalent pairing to the one used in the source text. Entrenched constructions "suggest themselves as first choices for translators" [42, p. 182], being chosen faster and more easily because of "a high frequency of SL and TL items as translations of one another" [43, p. 318], e.g. transfer of power - передача влади, the citizens of America громадяни Америки. ${ }^{\dagger}$ Fourth, though constructions have a fixed structure, they allow some modifications due to the slots available in their form, i.e. participant roles associated with a construction or a verb [10, p. 49]. Hence, a target construction allows certain transformations in order to bring the source pairing closer to the addressee, e.g. little to celebrate - мало приводів для свят. In the cited example, the pronoun 'little' from the source construction is modified by the noun ' приводів' in the Ukrainian pairing to specify the entity it refers to. Thus, constructions are "key elements in the organization and distribution of meaning over the different linguistic elements" [7, p. 284], accounting for variations in meaning in the original and translated pairings.

There are several classifications of constructions [see: 44, p. 102]. Syntagmatic study of prefabricated pairings, focusing on their linear expansion, allows to analyze their translation variants. Constructions fall into immediate, modified and extended. Immediate constructions consist of a word with dependent units joined on the left, e.g. gracious aid, or on the right, e.g. the rewards of government. Immediate modified constructions admit additional elements expressed by adjectives, cf. share destiny vs share glorious destiny, or pronouns, cf. control government vs control our government. Extended constructions combine two or more immediate ones, e.g. a new vision will govern our land. In the cited sentence, the immediate modified construction govern our land is extended by the unit $a$ new vision.

The constructionist method applied to the study of translating the inaugural address consists of four-steps, comprising both distributional and transformation investigation.

The first step consists in singling out constructions used by President Trump in his speech and the related pairings in Ukrainian translation, e.g. from the face of the Earth -3 лиия землі; America First-Америка передусім.

\footnotetext{
${ }^{\dagger}$ examples are taken from President Trump's inaugural and its translation into Ukrainian
} 
The second step presupposes dividing them into equivalent and non-equivalent pairings. Equivalent constructions have the same lingual form, i.e. maximally similar structure and meaning, e.g. gracious aid-люб'язну допомогу. In the example, the adjective in both pairings indicates kind and cordial help, with the original component gracious denoting behaviour marked by kindness and courtesy [45] and the lexeme люб'язну representing demeanor full of attention and cordiality [46].

Non-equivalent constructions involve transformation of the structure and semantics. Therefore, the third step relies on studying both the structure and the meaning of the related constructions and dividing them into units with syntactical or lexical modifications. Thus, in the pair debate our disagreements honestly - чесно обговорювати наші розбіжності we observe the change of word order, so the transformation is syntactical. Lexical modification involves the change of semantics, as is the case with the pair the factories shuttered-заводи й підприсмства закривались. In this case, there is meaning specification to match the worldview of the target audience.

The fourth step of the research implies classification of the singled out pairings into groups based on procedures performed by the translator. To determine the procedure carried out to transform the source construction syntactically we analyze omission of elements of the target construction, changes in grammar forms of the verb and the word order of the construction components, e.g. became the rulers of this nation again - зновy став правителем намої наиіï. In the example, we observe the procedure of permutation, i.e. the change of word order: the source pairing contains the adverb highlighting the repeated event at the end of the sentence, while in the translated construction we see it at the beginning.

Lexical transformations of constructions involve change of the key components meaning due to three procedures: generalization, simplification and specification. Generalization of the key component is carried out when the translated construction designates a broader scope of entities, e.g. have borne the cost - ніс на собі весь mяzар. In the cited example, the component 'cost' denoting amount of money paid by an individual [45] is translated into Ukrainian with the help of the lexeme 'mягар' reflecting more entities: duties, calamities and troubles [46]. Simplification of the constructional meaning is reflected by omitting the reference to the object from the source construction in the translated pairing, e.g. we are black or brown or white -ми чорні, чи білі. The procedure of specification relies on inserting linguistic units into the target construction, e.g. a total allegiance - иілковита і безумовна вірність. In the cited pair, the adjectival construction in the SL is specified by one more adjective to underscore the degree of loyalty.

The application of the four-step translation procedures based on the comparison between original and translated texts begins with the research of equivalent constructions. Then, the procedures described above are applied to pinpoint the changes used by the translator of President Trump's inaugural address.

\section{Results}

The application of morphosyntactic constructions to translating the inaugural address of President Trump has yielded the following results. Procedures chosen by the translator are determined by the scope of events denoted by the source constructions. Thus, the target constructions indicating global events understood to a wide public, are translated by means of equivalent constructions, while local events, which reflect intercultural discrepancies, by non-equivalent ones. 


\subsection{Equivalent constructions}

The global events are applicable to the situations in any country, can be easily accessible to citizens of the world and reflect concepts that are so typical or recurrent that they are entrenched in the mind of everyone, thus needing little or no explanation. As a result, translation procedures rest on rendering constructions in the SL by equivalent pairings in the TL that have maximal or optimal similarity in their structure and meaning to source constructions. The two structures, "consist of the same number of lexical words, representing equivalent grammatical categories, arranged in the same linear order" [43, p. 316]. Depending on the number of components equivalent constructions split into microconstructions, encompassing several words, and macroconstructions, including whole sentences.

The events represented in President Trump's inaugural translated by equivalent microconstructions reveal the following aspects:

a) entities concerning political life of the country, e.g. determine the course of America - визначати курс Америки; reinforce old alliances - зміцнювати старі союзи; with the nations of the world - з народами свіmy; seek friendship and goodwill-шукати дружби і доброї волі;

b) dire economic situation which the Obama's administration must stand guilty for, e.g. at the expense of American industry - комтом американської індустрї; and the crime and gangs and drugs - I злочинність, і банди, і наркотики; unrealized potential нереалізованого потенціалу;

c) renewal of the country, e.g. rebuilding our country - відновлюючи нашу країну; unlock the mysteries of space - розкрити таємниці космосу; the wealth, strength, and confidence of our country - достаток, сила і впевненість нашої держави;

d) calls for patriotism, e.g. our loyalty to our country - нашу вірність до намої країни;

e) omnipresent references to God [29, p. 2411], e.g. God's people-Божий народ; we are protected by God - нас оберizaє Госnодь;

Equivalent macroconstructions, consisting of whole sentences, are rendered into Ukrainian via equivalent pairings as the denoted notions meet the basic need - in security [37], e.g. We will bring back our jobs. We will bring back our borders. We will bring back our wealth. And we will bring back our dreams - Ми повернемо наші робочі місия. Ми повернемо наші кордони. Ми повернемо наше багатство. І ми повернемо наші мрії.

\subsection{Non-equivalent constructions}

Non-equivalent constructions have no ready counterpart in the TL, due to the absence of 'identical' in structure or meaning pairing, resulting in the 'constructional mismatch' [7, p. 287]. Thus, translators have to resort to the procedures of re-distributing the information, deciding which bits of it to highlight and which to background [ibid]. In the translation of President Trump's inaugural address, the translator has applied the procedures of both syntactical and lexical transformations of the source constructions, i.e. modifications of the structure and the meaning of the original pairings respectively.

Syntactical transformations involve four procedures: permutation, i.e. the change of word order; grammar changes; omission of components of the original pairings and condensation of several constructions.

Permutation concerns the order of usage of adverbs and adjectives. Adverbs indicating the time of action are used at the beginning of sentences, i.e. in the strong position to attract the addressee's attention, instead of the end, e.g. Everyone is listening to you now - Tenep усі слухають вас; or instead of the mid-sentence position, e.g. our soldiers will never 
forget - ніколи не забували наші солдати. Moreover, if there are two adverbial constructions, their position may be reversed to underscore the importance of the event in history, e.g. That all changes - starting right here, and right now - Все ие зміниться 3 цього дня. Саме туm. The adverb is placed before the verb in the corresponding Ukrainian construction to highlight the manner of action, e.g. eradicate completely повністю викорінимо; speak our minds openly - відкрито говорити, щзо думасмо. Тhe change of order of adjectives in the target construction shifts the attention to the feature of transferring the power smoothly, without violence, which must be topical for the readers in Ukrainian, e.g. the orderly and peaceful transfer of power - мирної та упорядкованої передачі влади.

Grammar changes result in the transformations of verb tense, substitution of modal verb, subjects and nouns. The change of verb tense concerns the usage of the past tense in the target construction instead of the present tense in the original pairing to underscore the result of the event, e.g. which party controls our government-яка партія отримала контроль над урядом; The oath of office I take today - Присяга, яку я склав сьогодні. The transformation of the present tense into the future one designates the president's pledge, e.g. This American carnage stops right here - американська бійня припиниться mym. The alternation of the non-continuous aspect into continuous highlights that the actions took much time, underscoring the long process, e.g. We've made other countries rich-Ми збагачували інші краӥни. The change of modal verbs in the source constructions reflects meaning modification: from the resolution to perform an action to the necessity to do it, e.g. We will follow two simple rules - B иій справі ми повинні керуватися двома простими принципами; from recommendation to necessity that has a stronger rhetorical effect on the target readers, e.g. There should be no fear-Ми не повинні нічого боятися. Change of subjects manifests itself in the substitution of predicative construction in the target pairing for the subject-predicate construction in the source one. Thus, the entity denoted by a single subject is made responsible for both actions and events, e.g. Washington flourished - but the people did not share in its wealth - Вашингтон процвітав, але не ділився $з$ народом своїми багатствами. Change of a noun construction into a pronoun one makes the translated pairing easier for perception, e.g. When America is united, America is totally unstoppable - Коли Америка об'єднана, їі неможливо зупинити.

Omission of components in the source construction results in the syntactic simplification of extended pairing to make the text more legible. In this case the translator drops conjunctions, e.g. Today's ceremony, however, has very special meaning - Нинішня церемонія набуває особливого значення; discourse markers, e.g. Finally, we must think big - Ми повинні мислити масштабно; adverbs, e.g. Now arrives the hour of actionПрийшов час діяти; and intensifiers, e.g. has very special meaning - набуває особливого значення. Repetition is also omitted. In the source constructions, repeated units fulfil the function of highlighting every idea and drawing attention to it. In the translated speech, the left out elements of constructions create the effect of unanimity due to omitted prepositions, e.g. Every decision on trade, on taxes, on immigration, on foreign affairs - Кожне рімення щзодо торгівлі, податків, імміграції, іноземних справ; and eliminated possessive pronouns, e.g. Your voice, your hopes, and your dreams, will define - Bam голос, надії і мрії будуть визначати. Because of omission, extended target constructions are changed into modified translated ones with the help of eliminated adjectives. This transformation is carried out to underscore inseparability of denoted entities, e.g. American hands and American labor - американськими руками і працею; to address all people instead of a separate nationality, e.g. giving it [power] back to you, the American people повертаємо ї̈ вам, людям. 
Construction condensation manifests itself in contracting several extended original constructions into one translated pairing to make the speech more energetic and laconic, e.g. Together, We Will Make America Strong Again. We Will Make America Wealthy Again. We Will Make America Proud Again. We Will Make America Safe Again. - Pазом ми знову зробимо наиу краӥну сильною, багатою, гордою, безпечною.

Lexical transformations of source constructions implemented in translating President Trump's inaugural address include all three procedures: simplification, generalization and specification.

The procedure of construction simplification is achieved by narrowing the scope of denoted objects. The target pairing indicates smaller amount of represented entities, e.g. have stolen too many lives - вкрали стільки життів. In this case, the source construction 'too many lives' underscoring the unacceptable amount [45] is rendered in Ukrainian by the pairing 'стільки життів' to designate an indefinitely big number of entities [46]. Lexical simplification of the translated construction limits the number of represented features of the objects or phenomena, e.g. good jobs-zidнa poбoma. In this pair, the source construction reflects evaluation of the job, it being of high quality and standard, while the target pairing indicates the status of the job. The most famous construction of Trump - American carnage - is rendered as американська бійня in which the noun 'carnage' implying death and destruction of the country [45] is replaced with the Ukrainian variant which underscores only mass extermination of people and animals [46].

Simplification of the source construction may reflect sparse activities carried out by the performers of an action due to the shift in the mode of its representation or the number of taken actions. Only perceptual mode of protection is taken into account in the pair refusing to defend our own [borders] - не стежили за власними рубежами. Definitely, the guard of national borders includes more tasks and duties than the translated pairing implies, namely the verb 'не стежили' which denotes border surveillance [46]. The change in the number of undertaken actions in the translated construction in comparison to the source pairing also reflects the procedure of lexical simplification, e.g. God Bless You-Xaŭ Господь береже всіх нас. In the cited example, the notion of blessing in the English construction implies help and protection [45], while the target pairing is narrowed to safety and security, though there exists an equivalent pairing in the Ukrainian language.

The modification via the procedure of simplification encompasses the correlation of the performer and the experiencer. Original constructions reflect Americans as more active than the translated variants, e.g. for struggling families - для стражженних сімей. In this example, the source construction represents people making great efforts, striving to overcome hardships, while the Ukrainian variant reflects an individual full of sufferings and enduring them. Target constructions underscore passive role of the citizens due to lexical simplification, e.g. will combat hardships - чекають труднощi. The English pairing will combat hardships highlights that a person accepts the fact that difficulties exist and tries to deal with them, while the Ukrainian pairing 'чекають труднощі' represents a passive individual in the face of coming hardships. Lack of aspirations and desire to act is observed in the pair Mothers and children trapped in poverty - Maтері й діти ледь животіють $y$ злиднях. The original construction indicates unpleasant situation families cannot escape, but the Ukrainian corresponding pairing represents life in dreadful conditions, with adversities and, in fact, no sense in life, and this terrifying situation is intensified by the adverb 'ледве'.

The operation of generalization is not widely represented in the translated text which can be explained by the desire of its author to decrease the amount of cognitive effort necessary for the understanding of the ceremonial speech by the addressee. The models of lexical generalization in the Ukrainian translation encompass the schematisation of nominal and verbal components of the source pairings. 
The nominal generalization of the source construction reflects the entity in a more abstract way because it applies to a bigger number of referents, e.g. the establishment protected itself-вищі класи захищали себе. In the cited example, the English pairing refers to people in power, while 'вищі класи' implies elite though there is a noun 'естеблішмент', thus the translator makes the Ukrainian construction easier for understanding. The nominal element in the translated pairing can be applicable to more entities, e.g. glorious destiny - славне майбутнє. The English construction indicates things people will do in their future [45], while the corresponding noun in the target pairing represents all the possible events in time following the present [46]. The modified Ukrainian construction reflects the choice of the less culturally charged variant.

Generalization of verbal components of the translated constructions reflects the decrease of pathos implemented by the President in his inaugural. The specific word choice invokes particular emotions and feelings, in case of President Trump a powerful tool to impress the addressee. The corresponding constructions in Ukrainian reflect a more neural representation of problems in the country and its future. Trump's criticism of the Obama's administration concerns education and criminality. The constructions Trump uses appeal to

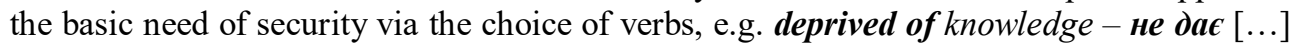
достатніх знань. In the cited example, the original pairing has a negative connotation: it refers to force exercised by the previous government which, according to President Trump's words, prevented youth from getting knowledge. The Ukrainian construction underscores only the process of obtaining knowledge. Criminal issues are represented via pathos, i.e. appeal to human emotions, e.g. the crime and gangs and drugs [...] robbed our country of so much unrealized potential - злочинність, $i$ банди, i наркотики [...] лишили у нашої країни так багато нереалізованого потенціалу. The source pairing highlights the illegal act of the previous administration appealing to the need in security, whereas the translated construction reflects the situation in a neutral way.

The vision of the future by President Trump is generalized in the translated constructions, so that it seems less aspiring, e.g. restore its promise- здійснення обіџянок. The original pairing indicates renewal of the entity, implying that the promise has already been made and thus the linguistic unit appeals to human desire to go back to 'good old times', while the corresponding target pairing used at the superordinate level of categorization represents just fulfillment of the statement. The promise of the American president is reflected by a metaphorical construction lift our sights implying improvement, scalar movement up the path of people's expectations. In its turn, the pairing визначати наш погляд indicates establishing ideas, settling plans, thus presenting the notion in a less emotional way due to the connotative meaning of the linguistic unit under analysis. The pathos reveals itself in the usage of tautology in the original construction underscoring the rhetorical effect while the translated variant presents a neural picture, e.g. we all bleed the same red blood - y всіх нас тече та ж червона кров. In the original speech the immediate construction 'bleed the blood' denotes the outflow of blood in case of wound or cut caused by some deliberate damage [45], while in the target construction the blood flows naturally, as a result, the translator eliminates the violent image that could be created in the addressee's mind.

Specification as a procedure of lexical transformation is represented by various models: repetition, insertion and substitution.

Modified target constructions based on repetition of separate elements emphasize the period, e.g. for years to come - баzаmo-баzаmo років вперед; For many decades Десятиліття за десятиліттям; or the sum of money, e.g. trillions of dollars трильйони і трильйони доларів.

Specification via inserting separate elements adds emotiveness to the Ukrainian version with the help of intensifiers, e.g. a different reality - зовсім інша реальність; оr 
conventional expression of gratitude absent from President Trump's speech to make the translated text more polite, e.g. They have been magnificent-Вони були прекрасні. Дякую

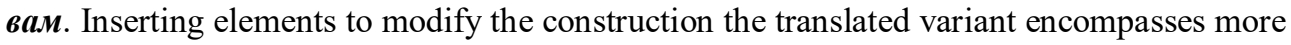
referents typical of the Ukrainian worldview, e.g. the factories shuttered-заводи й підприємства закривались; reasonable demands of a righteous public - розумні вимоги доброчесних людей $і$ доброчесного суспільства.

Substitution relies on replacing verbal components of the source construction with those, characterizing the actions, in order to give additional information, e.g. a different reality exists - переслідує зовсім інша реальність. In the cited example, the English existential verb is replaced by the verb of motion 'переслідує' in the TL designating the chase of a person, threatening them with possible consequences [46]. In such a way, the translation underscores the dire situation in the USA as seen by President Trump. The substituted verb indicates different stages of activity, e.g. are infused with the breath of life - вирус життя. In this case, the source pairing denotes the initial stage of life, while the translated construction specifies the active state full of emotions and events.

Adaptation of the original construction to the TL implies transformation of the source construction to reflect local peculiarities. Such adaptive modifications include typical ways of greeting, grammar structures and deictics.

Adaptive greeting underscores differences in attitude to guests. The English construction fellow Americans indicates people having something in common with the rhetor so that the president implies his close connection with the audience, his electorate, while the Ukrainian modification дорохі американці serves as a typical greeting in our culture highlighting how precious and important the public is.

Adaptation of grammar structure concerns pronouns and nouns. President Trump emphasizes his focus on every citizen, making the speech more personal with the help of the pairings containing pronouns 'every' and 'each', while Ukrainian modified pairings include the pronoun ' $в c i$ ' (all) to underscore unity, e.g. in every hall of power -8 ycix коридорах влади; for everyone to follow - для наслідування всім іншим. Adaptive modification of nominal constructions represents economic concepts in the singular in Ukrainian variants, e.g. harness the energies, industries - мобілізувати енергію, промисловість; and nationalities in the plural to include more citizens, e.g. Buy American and Hire American - купуй американське і наймай на роботу американців.

There are cases of adapting deictics in the Ukrainian version of the inaugural, e.g. this nation-нашої нauiï; avoiding unnecessary tautology in the TL as in Ukraine there is only one capital, e.g. in our nation's Capital - y столиці.

Complex transformations rest on two or three translation procedures to modify the original construction. Double transformation includes two types of modification of the source pairing, e.g. has very special meaning- набуває особливого значення. The translated correspondence indicates the transformation of omission (very) and specification of the verbal element that in the Ukrainian pairing underscores obtaining a quality, gradual acquisition of the feature [46]. Translation procedure of triple transformation of an original construction results in three various types of its modification, e.g. across the landscape of our nation - по наших мальовничих пейзажах. In this case, there are the modifications of specification by adding the evaluative adjective 'мальовничих' into the target construction and generalization due to dropping the noun 'nation' underscoring the belongingness of the territory. Besides, we can see the changed word order, permutation, here as well.

To conclude, the two types of constructions used to translate President Trump's inaugural - equivalent and non-equivalent - highlight the transformation procedures which either represent the notions well-known to the general public in case with equivalent 
pairings or underscore realia and phenomena of local value which need additional efforts from the translator.

\section{Discussion}

The analysis of constructions used in the inaugural of American President Trump and its translation into Ukrainian is determined by the peculiarities of the source text which presents the leader to the world and underscores their ideas as for the next four years of government. Consequently, it is extremely vital to provide faithful translation producing the precise contextual meaning of the original within the constraints of the TL.

The research has revealed that the choice of the target constructions depends on whether the referents belong to the global level of worldview typical of both Americans and Ukrainians or to the national worldview which has discrepancies with the two cultures.

The equivalent constructions construe the reality that is the same for the speakers of both languages as it addresses their basic needs. Such pairings preserve the original style and wording of the source text, its authenticity. Equivalent constructions are used throughout the translated text and denote entities from the fields of political and economic situations, patriotic feelings, fight for freedom and references to God. The translation procedures rely on the search for almost identical, maximally similar correspondences in the TL.

Non-equivalent constructions reflect constructional modifications during which the translator has to find the closest variant as there is no accurate one. The investigation of the Ukrainian translation of President Trump's inaugural indicates numerous application of the strategy of domestication that transforms the original text in such a way as to bring it closer to the addressee by replacing American realia with those characteristic of Ukrainian politics and culture. The modified target constructions reflect perception of the president, the role of the government in the life of the country and the features of Americans.

First, transformations change the image of the president. Generalized modified constructions affect the rhetorical peculiarities of the inaugural. President Trump is known to be emotional, appealing to pathos in his choice of linguistic units, whereas the translation demonstrates neutral representation of events. Pairings modified with the help of insertion or substitution emphasize Trump's negative presentation of problems in the country caused by the previous administration, accentuate Trump's pledges and amplify politeness to his speech in order to improve his image for the target audience. Besides, modified constructions presenting events in the past instead of the present or the future highlight the results of the elections and President Trump's achievements not emphasized in the original speech.

Second, there are modified constructions underscoring the activity and significance of the government that plays a vital role in the worldview of Ukrainians. This is achieved by changing grammatical categories, namely substituting modal verbs denoting necessity for those indicating recommendation or intention, the translator represents the leading role and the unconventional value of the president's words still typical in Ukrainian culture. Syntactical transformation of permutation is reflected in the target constructions indicating the time of the event in the strong position, i.e. at the beginning of the sentence or paragraph, to intensify the significance of the inauguration in history.

There are examples of interlingual modifications when translated constructions, which are transformed with the help of simplification, represent Americans as passive, unable to resist difficulties and challenges, while English pairings portray them as active, ready to retaliate against the obstacles. This transformation procedure - from active into passive brings the inaugural closer to the target audience via adaptation to their worldview. 
Thus, the prevailing number of modified constructions were translated in accord with the strategy of domestication. As the inaugural address demands faithful translation to reveal the real stance of the president, the target text under analysis is not adequate and lacks American features and Trump's 'spirit'. The applied modification procedures reveal the desire of the translator to make the speech more understandable for a nonprofessional having little knowledge of the processes and traditions of the American political system.

\section{Conclusions}

The investigation proves that constructionist approach can be applicable to translation studies. The affinity between composing a speech and translating it lies in the fact that both operate with meaning and go through the stage of mental representation of the content before starting working with the linguistic material. Constructions can be a key to solving translation problems as they activate meaning and provide broader linguistic material for the choice of translation procedures. Modifications of the source constructions help to achieve faithful and accurate translation of a text providing equivalence of content, text type and style. The perspectives of further research consist in applying constructions as form-meaning pairings to contrast various translations of the same inaugural address, to investigate types of constructions implemented to translate other types of political discourse, to reveal manipulative potential of the transformation procedures carried out by the translator of political speeches.

\section{References}

1. Cognitive linguistics and translation: Advances in Some Theoretical Models and Applications (eds Ana Rojo and Iraide Ibarretxe-Antunano) (Walter de Gruyter, Berlin/Boston, 2013)

2. V. Evans, M. Green, Cognitive Linguistics: An Introduction (Edinburgh University Press, Edinburgh, 2006)

3. W. Croft, D. A. Cruse, Cognitive linguistics (Cambridge University Press, Cambridge, 2004).

4. J. M. Lauer, Invention in Rhetoric and Composition (Parlor Press, West Lafayette , Indiana, 2004)

5. S. Tirkkonen-Condit, Meta 50 (2), 405-414 (2005)

6. M. L. Larson, Meaning-Based Translation: A Guide to Cross-Language Equivalence (University Press of America, New York, London, 1984)

7. A. Rojo, J. Valenzuela, Cognitive linguistics and translation: Advances in Some Theoretical Models and Applications, 283-310 (Walter de Gruyter, Berlin/Boston, 2013)

8. D.Alamargot, L. Chanquoy, Through the models of writing (Kluwer Academic Publishers, Dordrecht-Boston-London, 2001)

9. R. Jääskeläinen, Meta 41 (1), 60-74 (1996)

10. A. E. Goldberg, Constructions: A construction-grammar approach to argument structure (University of Chicago Press, Chicago/London, (1995)

11. A. E. Goldberg, Construction at Work: The Nature of Generalizations in Language (Oxford University Press, Oxford, 2006)

12. M. Tomasello, Constructing a Language: A Usage-Based Theory of Language Acquisition (Harvard University Press, Cambridge, USA/London, UK, 2003)

13. A. Goldberg, Trends in Cogn. Sc. 7(5), 219-224 (2003) 
14. E. Dąbrowska, Language, Mind and Brain (Edinburgh University Press, Edinburgh, 2010)

15. N. Gisborne, Cogn. Ling 22, №1, 155-182 (2011)

16. P.Wasserscheidt, Constr. and Fr. 6(2), 305-337 (2014)

17. K. K .Campbell, K. H. Jamieson, Presidents creating the presidency: Deeds done in words (University of Chicago Press, Chicago, (2008)

18. D. J. Trump, The inaugural address Retrieved from http://whitehouse.gov/inauguraladdress (2017)

19. Inauguration address of Donald Trump Retrieved from https://uk.wikisource.org/wiki/\%D0\%86\%D0\%BD\%D0\%B0\%D0\%B2\%D0\%B3\%D1 $\% 83 \% \mathrm{D} 1 \% 80 \% \mathrm{D} 0 \% \mathrm{~B} 0 \% \mathrm{D} 1 \% 86 \% \mathrm{D} 1 \% 96 \% \mathrm{D} 0 \% \mathrm{~B} 9 \% \mathrm{D} 0 \% \mathrm{BD} \% \mathrm{D} 0 \% \mathrm{~B} 0 \% \mathrm{0} 0 \% \mathrm{BF}$ $\% \mathrm{D} 1 \% 80 \% \mathrm{D} 0 \% \mathrm{BE} \% \mathrm{D} 0 \% \mathrm{BC} \% \mathrm{D} 0 \% \mathrm{BE} \% \mathrm{D} 0 \% \mathrm{~B} 2 \% \mathrm{D} 0 \% \mathrm{~B} 0 \% \mathrm{D} 0 \% 94 \% \mathrm{D} 0 \% \mathrm{BE} \% \mathrm{D}$ 0\%BD $\%$ D0\%B0\%D0\%BB\%D1\%8C\%D0\%B4\%D0\%B0_\%D0\%A2\%D1\%80\%D0\% $\mathrm{B} 0 \% \mathrm{D} 0 \% \mathrm{BC} \% \mathrm{D} 0 \% \mathrm{BF} \% \mathrm{D} 0 \% \mathrm{~B} 0$ (2017)

20. L. Venuti, Encyclopedia of translation studies 240-244 (Routledge, London and New York, 1998)

21. P. Newmark, Approaches to Translation (Prentice Hall, Hertfordshire, 1988)

22. G. Young, W. B. Perkins, J. of Pol. 67(4), 1190-1205 (2005)

23. C. J. Chung, H. W. Park, Soc. Sc. Inf. 49(2), 215-239 (2010)

24. M. J. Korzi, Congr. \& the Pres: A J of Cap. St. 31(1), 21-52 (2004)

25. Q. Zhou, B. Kazemian, Int. J. of Lang. and Ling. 4(1-1), 10-16 (2015)

26. P. Widiatmoko, Eng. Rev.: J. of Eng. Ed. 5(2), 275-282 (2017)

27. V. Beasley, Com. Mon. 68(2), 169-183 (2001)

28. H. Gruber, Analyzing genres in political communication 29-71 (John Benjamins, Amsterdam, 2013)

29. F. Liu, Th. and Pr. in Lang. St. 2(11), 2407-2411 (2012)

30. G. Kennedy, A New History of Classical Rhetoric (Princeton University Press, New Jersey, 1994)

31. G. A. Hauser, Introduction to Rhetorical Theory (Waveland Press, Long Grove, 2002)

32. J. Golden, Rhetoric of Western Thought (Kendall/Hunt Publishing Company, Dubuque, 2003)

33. K. K. Campbell, Encyclopedia of rhetoric, $517-527$ (Oxford University Press, Oxford, 2007)

34. Aristotle, The Art of Rhetoric (World Heritage Encyclopedia Publisher, Honolulu, 2008)

35. L. D. Green, Encyclopedia of Rhetoric, 645 (Oxford University Press, Oxford, 2006)

36. S. Potapenko, Deeds and Days 66, 155-166 (2016)

37. A. Maslow, Motivation and Personality, 35-47 (Harper \& Row Publishers, New York, 1970)

38. M. Hilpert, Germanic future constructions: A usage-based approach to language change (John Benjamins Publishing, Amsterdam, 2008)

39. H. M. Eckhoff, Old Russian possessive constructions: A construction grammar approach (Mouton de Gruyter, Boston, 2011)

40. A. E. Goldberg, Explain Me This. Creativity, Competition, and the Partial Productivity of Constructions (Princeton University Press, Princeton, 2019).

41. A. Zeschel, New Directions in Cognitive Linguistics, 185-200 (Bangor University Press, Bangor, 2009)

42. S. Tirkkonen-Condit, Translation Universals. Do they exist? $177-184$ (John Benjamins, Amsterdam, 2004)

43. S. Halverson, Tr. Sp. 4(2), 310-340 (2015)

44. N. Talavira, Ling. Posn. 59(2), 101-120 (2017) 
45. Merriam-Webster Dictionary, Access at https://www.merriam-webster.com/ 46. The Dictionary of the Ukrainian Language, Access at http://sum.in.ua/ 